\title{
THE
}

\section{Family-school connections and internalizing problems among children living with asthma in urban, low-income neighborhoods}

\author{
Karla Klein Murdock \\ Elizabeth M. Robinson \\ Sue K. Adams \\ University of Rhode Island, suekadams@uri.edu \\ Jennifer Berz \\ Michael J.D. Rollock
}

Follow this and additional works at: https://digitalcommons.uri.edu/hdf_facpubs

This is a pre-publication author manuscript of the final, published article.

Terms of Use

All rights reserved under copyright.

\section{Citation/Publisher Attribution}

Murdock, K. K., Robinson, E. M., Adams, S. K., Berz, J., \& Rollock, M. J. D. (2009). Family-school connections and internalizing problems among children living with asthma in urban, low-income neighborhoods. Journal of Child Health Care, 13(3), 275-294. https://doi.org/10.1177/ 1367493509336682

Available at: https://doi.org/10.1177/1367493509336682

This Article is brought to you for free and open access by the Human Development and Family Science at DigitalCommons@URI. It has been accepted for inclusion in Human Development and Family Science Faculty Publications by an authorized administrator of DigitalCommons@URI. For more information, please contact digitalcommons-group@uri.edu. 


\title{
Family-school connections and internalizing problems among children living with asthma in urban, low-income neighborhoods
}

\author{
KARLA KLEIN MURDOCK, PhD, \\ Associate Professor, Department of Psychology, Washington and Lee University, Lexington, VA, \\ USA
}

ELIZABETH M. ROBINSON, BA,

Postbaccalaureate Fellow, Prevention Research Branch, Eunice Kennedy Shriver National Institute for Child Health and Human Development, Bethesda, MD, USA

SUE K. ADAMS, PhD,

Assistant Professor, Department of Human Development and Family Studies, University of Rhode Island, Kingston, RI, USA

JENNIFER BERZ, PhD, and

Family and Child Clinician, Brookline Community Mental Health Center, Boston, MA, USA

MICHAEL J.D. ROLLOCK, MA

Clinical Psychology PhD Candidate, University of Massachusetts, Boston, MA, USA

\section{Abstract}

Children with asthma living in urban environments are at risk for experiencing internalizing problems and difficulties at school due to social context and health-related stressors. Parent confidence and participation in the school and children's attitudes about school were explored in association with children's depressed mood and school anxiety. Forty-five parent-child dyads were recruited from urban community health centers. most participants were members of ethnic minority groups. Hierarchical multiple regression analyses revealed that higher levels of parent confidence in the school were associated with fewer symptoms of school anxiety in children. Children's attitudes toward school moderated the relation between parent participation in the school and children's depressed mood. Specifically, lower levels of parent participation were

\footnotetext{
(c) The Author(s), 2009.

Correspondence to: Karla Klein murdock, Department of Psychology, Washington and lee university, lexington, VA 24450, uSA. [murdockK@wlu.edu].

KARLA KLEIN MURDOCK is an associate professor in the Department of Psychology at Washington and Lee University. Formerly she taught in the University of Massachusetts Boston Clinical Psychology PhD program. Her research focuses on psychosocial adjustment among children and families coping with stresses such as socioeconomic disadvantage, chronic illness and developmental transitions.

ELIZABETH M. ROBINSON is Postbaccalaureate Fellow at the Prevention Research Branch within the Eunice Kennedy Shriver National Institute for Child Health and Human Development. Her research interests include coping with chronic illness as it impacts psychosocial adjustment and family functioning in pediatric populations.

SUE K. ADAMS is an assistant professor in the Department of Human Development and Family Studies, University of Rhode Island. Her research interests include factors that influence health disparities in childhood asthma. She also investigates the associations among sleep and psychological and academic well-being in college students.

JENNIFER BERZ is a family and child clinician at the Brookline Community Mental Health Center in Brookline, MA. Her research has addressed demographic and psychosocial correlates of pediatric asthma.

MICHAEL J.D. ROLLOCK is an advanced doctoral candidate in the clinical psychology graduate program at the University of Massachusetts, where he provides clinical service in the counseling center and teaches undergraduate courses. His clinical work and scholarship considers interpersonal, familial and psychological well-being and processes, particularly in underserved, minority adolescents, intimate couples and families, from a strength-based, developmental-ecological perspective. His dissertation research examines the interpersonal benefits that may be conferred on couples who engage in joint prosocial behavior.
} 
associated with higher levels of depressed mood only for children with the least positive school attitudes. Although preliminary, these results suggest the importance of attending to family-school connections to optimize the school-related psychological functioning of children living with asthma in urban environments.

\section{Keywords}

child and adolescent mental health; child health; inequalities in health; parenting support

\section{Introduction}

In the United States, asthma affects an estimated 6.8 million children under the age of 18 and is the third leading cause of hospitalization in children aged 15 and under (American Lung Association, 2007). Children from minority ethnic backgrounds who live in lowincome, inner-city environments experience disproportionately higher levels of morbidity and mortality due to asthma (Castro et al., 2001; Rana et al., 2000). Asthma has been associated with compromises in fundamental elements of children's school-related functioning, such as absence (Diette et al., 2000; Koinis mitchell et al., 2005; Moonie et al., 2006), academic performance (Bender, 1995; Diette et al., 2000) and psychosocial wellbeing (Goodwin et al., 2005; Mcquaid et al., 2001; Taras and Potts-Detema, 2005).

\section{Pediatric asthma, school and internalizing in urban environments}

Asthma-related functional impairment is a particular problem among children at psychosocial risk by virtue of their socioeconomic, minority ethnic and/or cumulative risk status (Josie et al., 2007; McLoyd, 1998; Moonie et al., 2006; Newacheck and Halfon, 2000). Children's physiological health and social context interact to affect their school performance. The stacked risks of low income, urban residence and asthma have been associated with lower school readiness and academic performance (Gutstadt et al., 1989; Halterman et al., 2001). In a sample of more than 10,000 children, grade failure was three times as likely among children with asthma of lower socioeconomic status compared to children with asthma of higher socioeconomic status and twice as likely among children of low socioeconomic status with asthma when compared to children without asthma of the same socioeconomic status (Fowler et al., 1992). It is crucial to clarify the psychosocial pathways affecting the academic outcomes of children living with asthma in low socioeconomic status environments.

The overall psychosocial functioning of children is likely to underlie their academic engagement and success (Birmaher et al., 2004; Chorpita and Southam-Gerow, 2006). Children with asthma are at risk for experiencing higher levels of psychiatric (Brown et al., 2000; Goodwin et al., 2005; Vila et al., 2000), behavioral (McQuaid et al., 2001) and psychosocial (Meuret et al., 2006) impairment than their physically healthy peers. Pediatric asthma has been associated with elevated risk for internalizing problems such as depressed mood and anxiety (Bender et al., 2001), even compared to other pediatric illnesses such as cancer or diabetes (Padur et al., 1995). Children and adolescents with asthma have increased rates of anxiety disorders (Goodwin et al., 2005) and panic attacks (Goodwin et al., 2003), and such comorbidity is associated with greater functional impairment (Katon et al., 2006; Ross et al., 2007). The onset of asthma by age five has been shown to significantly increase the likelihood of developing internalizing problems by age 14 (Alati et al., 2005).

Internalizing problems and asthma are associated independently with activity restrictions related to school functioning. Anxiety and other internalizing symptoms correlate with 
compromises in multiple aspects of children's engagement in and adaptation to school activities and relationships (Bender, 1995; Russell and Russell, 1996), and can be associated with significant and/or lasting impairments including poor school performance and social functioning (Bell-Dolan and Wessler, 1994; Kendall et al., 1992; Langley et al., 2004; Silverman and Ginsburg, 1998). In a study of activity restriction among children with asthma, diabetes, cancer and healthy controls, parent reports of children with asthma indicated significantly greater impairment than comparison groups (Padur et al., 1995). Thus, children's experiences of asthma, internalizing problems and school experiences are likely to be intertwined in important ways.

Anxieties specific to the school environment have not been examined yet in connection with pediatric asthma. Children with asthma may be more prone than their physically healthy counterparts to experience symptoms of school phobia, defined as an avoidance of school due to overwhelming fearfulness (Kearney et al., 1995). The overlap of high rates of school absences (Fowler et al., 1992; Halterman et al., 2001) and elevated risk for depressed mood and/or anxiety among children with asthma may reflect an underlying form of school phobia. Thus, school-related anxiety could be an important and unrecognized consideration in the school functioning of children with asthma.

\section{Pediatric asthma in context: family-school connections}

Asthma carries different levels of risk for children in different social environments, and Bronfenbrenner's ecological systems theory provides a helpful framework for examining the contexts of children's health. His concept of the mesosystem refers to links or connections among components of the child's social environment (Bronfenbrenner, 1979, 1995; Bronfenbrenner and Morris, 1998). One aspect of the mesosystem, family-school connections, can be operationalized as parents' confidence and involvement in their children's school and children's attitudes toward school.

Given the demands on a child managing a chronic illness away from home, strong and positive partnerships between caregivers at home and school may serve as a particularly important function for children with asthma. In the general child development literature, parents' involvement in elementary education has been associated with benefits in children's school functioning, including academic performance (Adams, 1997; Shumow et al., 1999). A positive parent-school partnership has been associated with children's more positive attitudes toward school, better work habits, higher self-concept (Christenson et al., 1992; Epstein, 1990) and high schoolers' grade-point average and attendance (Adams, 1997). Among children living in high-risk neighborhoods, positive academic performance has been associated with positive parent-school partnerships (Shumow et al., 1999) and parents' positive attitudes toward school, teachers and the education that their children are receiving (Cherian and Cherian, 1996). Although barriers to strong family-school partnerships may exist in high-risk urban environments (Van Velsor and Orozco, 2007), parents are invested in their children's success in and attitudes towards school (Compton-Lily, 2000).

Children's own attitudes about school may be linked to their socio-emotional well-being. In a study of first to third-graders (children aged 6-9 years), children's attitudes toward individual academic subjects were associated with their achievement test scores in those areas (Diehl et al., 1998). However, a longitudinal study of children aged 7-16 years found few direct associations between children's attitudes and their academic achievement (Blatchford, 2007). Thus, although the construct of children's attitudes about school is a potential protective factor for their socio-emotional experience in school, these inconsistent findings suggest that children's attitudes may interact with other contextual variables, such as the parent-school partnership. 
The current study explored a hypothetical model linking family-school connections and children's internalizing problems (see Figure 1). Participants included parent-child dyads, most of whom were members of minority ethnic groups, living with pediatric asthma in low socioeconomic status, urban environments. It was expected that more positive parent-school partnerships (i.e. higher levels of parents' confidence and participation in their child's school) and children's positive attitudes toward school would be associated with fewer internalizing problems (i.e. depressed mood and school anxiety). In addition, it was expected that the child's attitudes toward school would moderate the relation between parent confidence or participation and the child's psychosocial functioning, such that families with a stronger parent-school partnership and children with more positive school attitudes would report the fewest internalizing problems.

\section{Method}

\section{Sample and procedure}

Children with asthma between the ages of seven and 10 years and their primary caregivers were recruited from five community health centers in boston, mA. Health center staff members generated mailing lists of children whose records indicated an asthma diagnosis and recruitment materials were mailed to their parents at home. Staff members also provided information to eligible families during children's medical appointments. All recruitment materials and assessment measures were made available in English and Spanish. Materials were translated from English into Spanish with forward, backward and consensus translation processes. For families who preferred Spanish, all verbal and written correspondences were conducted by native Spanish-speaking research assistants. Ethical approval for this study was given by the University of Massachusetts Boston Institutional Review Board.

Forty-seven families volunteered to participate. Parent-child dyads were interviewed in comfortable laboratory rooms at an urban university located in the recruitment neighborhood. Separate and confidential interviews with primary caregivers and children were approximately 90 minutes long. Thirteen caregiver interviews were conducted in Spanish by bilingual, native Spanish-speaking interviewers. With separate consent, data were collected from children's teachers and medical charts. Cab vouchers, parking passes and/or public transportation funds were provided, as well as free childcare for the siblings of participating children. A thank-you gift of $\$ 20$ and small prizes were provided to each participant.

\section{Measures}

Table 1 presents the descriptive statistics and internal consistency data for primary study variables and additional measures of interest.

\section{Data collection}

Demographic information was reported by the parent. An open-ended question was asked regarding the ethnic group(s) with which each parent and child primarily identified and these labels were categorized under the umbrella terms utilized by the Us Census Bureau (2002). Parental education was coded on a seven-point scale $(1=\operatorname{did}$ not finish high school to $7=$ master's degree or higher). Occupational prestige scores were determined for employed parents based on the National Opinion Research Center coding system (Nakao and Treas, 1990). These codes can range from 17-86, with higher scores indicating more prestige (e.g. sales associate in a clothing store: 30.22 ; preschool teacher: 54.93). Occupational prestige ratings of the employed primary caregivers in the current study ranged from 23.28 to 64.08 , with an average rating of 41.03 . To assess perceived socioeconomic status, participants 
completed the Scale of Subjective Status (Adler et al., 2000), in which they placed themselves on a 10-rung ladder with higher rungs reflecting greater social status.

Children's asthma severity ratings (where $1=$ mild intermittent to $4=$ severe persistent) were made by health care providers and recorded from medical charts for 32 children in this dataset. For 11 children, medical chart data were not available and asthma severity ratings were coded on the basis of parent-reported symptoms and medications following the 2002 National Asthma Education and Prevention Program guidelines (National Institutes of Health, 2002), which were the convention at the time of data collection. For two children, neither medical chart nor medication data were available and parent-reported severity ratings were utilized.

The children's average grades were reported by primary caregivers, who reported whether their recent grades were mostly As, Bs, Cs, Ds or Fs. In order to standardize inconsistent grading rubrics, initially the grades were standardized along a five-point Likert scale and a mean grade score was calculated for each child. Teacher-reported grades, which were available for 56 percent of the sample, were substituted for two missing parent reports. Parent reports were correlated significantly with available teacher-reported grade-point averages $(r=.48 ; p=.02)$. To address whether this correlation was skewed by teachers of the more academically accomplished students being more likely to participate, a $t$-test was conducted to compare parent-reported grades both with and without teacher-reported grades. No significant group differences were revealed.

\section{Parents' school confidence and participation}

A 20-item, parent-reported measure of the parent-school connection was developed for the current study. Factor analysis revealed three factors: parent confidence in the school or teacher, consisting of 11 items (e.g. 'You are confident that (the child's) teacher(s) is doing a good job teaching (them) academic skills'); parent participation in the school, consisting of three items (e.g. 'During the school year, how often have you attended parent-teacher conferences?'); and parent contact with the school. The current study addresses confidence and participation. Primary caregivers responded to items on the parent confidence subscale along a four-point Likert scale (from strongly disagree to strongly agree) and on the parent participation subscale along a five-point Likert scale (from never to always). Internal consistency was acceptable for both subscales in this sample (confidence $a=.93$, participation $a=.73$ ).

\section{Child's school attitudes}

The Self-Report Scale of the Behavioral Assessment System for Children (SRS-BASC) was administered to children, involving a series of statements to which they responded 'true' or 'false' (Reynolds and Kamphaus, 1998). The Attitudes Toward School subscale consists of eight items which describe a child's feelings towards school (sample item: 'You don't like thinking about school'). $T$-scores of 70 or above indicate the poorest attitudes and are considered clinically significant, suggesting an increased risk of dropping out. Scores ranging from 60-69 indicate that children are at risk and are considered to have a pervasive discomfort with school. Scores of 41 or below indicate the most positive attitudes and demonstrate relative satisfaction and comfort with school. In the normative sample containing children from diverse ethnic and socioeconomic backgrounds, this subscale had an internal consistency of .83 and test-retest reliability of .80 (Reynolds and Kamphaus, 1998). 


\section{Child's depressed mood}

The BASC-SRS depression subscale consists of 17 items assessing feelings of loneliness, sadness and inability to enjoy life (sample item: 'Nothing ever goes right for you'). Scores of 70 or above are considered to be clinically significant and indicate broad problems of adjustment. Scores ranging from 60-69 indicate significant levels of depression, and children scoring in this range are considered to be at risk. In the normative sample, the internal consistency of this subscale was .88 and test-retest reliability was .75 (Reynolds and Kamphaus, 1998).

\section{Child's school anxiety}

School anxiety was assessed with the following five items reflecting primary school refusal symptoms (Kearney and Bensaheb, 2006), to which primary caregivers responded either 'yes', 'no' or 'don't know': 'During the past year, has your child: (1) been afraid of school or excessively nervous about being at school; (2) refused to go to school for several days or more; (3) asked to go to the school nurse very often during class, even though there has not seemed to be anything physically wrong with them; (4) complained of sickness when you felt that they were not really ill, but just wanted to miss school; and (5) missed many days of school when you felt that they were physically healthy enough to go?' Higher scores indicate greater school anxiety. The internal consistency of these items was .64 in the current sample.

\section{Results}

Participants

Demographic information about the sample is presented in Table 2.

Two families were excluded from the current analyses due to missing data. The final sample included 23 girls and 22 boys (average age $=9.3$ years), all of whom had been diagnosed with asthma by a physician. Approximately 85 percent of children were members of minority ethnic groups. Children's asthma severity ratings were as follows: mild intermittent $(N=23)$, mild persistent $(N=8)$, moderate persistent $(N=13)$ and severe persistent $(N=1)$.

\section{Data analyses}

A correlation matrix of primary demographic and study variables is presented in Table 3.

Asthma severity was not correlated significantly with any primary study variables. Grades were significantly correlated with age $(r=-.41, p<.05)$ and depressed mood $(r=-.43, p<$. $05)$, but not with any predictor variable. Greater parent education was correlated significantly with poorer child school attitudes $(r=.38, p<.01)$. $T$-tests revealed no significant gender differences in primary study variables.

Hierarchical regression analyses were conducted to test the hypotheses. Separate regressions were conducted for parent confidence and parent participation with regard to each dimension of internalizing (depressed mood and school anxiety). In the first step of each regression model, parent confidence or participation was entered, in the second step, child school attitudes was entered, and in the third step, the interaction term (parent confidence or participation $\mathrm{x}$ school attitudes) was entered in order to test moderation. When parent education was controlled for in the first step of each hierarchical regression analysis, the same pattern of results emerged.

\section{Dependent variable: depressed mood}

The results for depressed mood are presented in Table 4. 
In the first regression, parent confidence accounted for a non-significant 5 percent of the variance. In the second step of the model, once parent confidence was taken into account, more positive child school attitudes were associated significantly with lower levels of depressed mood, accounting for an additional 21 percent of variance $(\beta=.47, p<.01)$ (note: higher BASC school attitudes scores indicate a less positive orientation toward school). The interaction between parent confidence and child school attitudes was not significant.

Parent participation did not account for significant variance in depressed mood. In the second step of the model, child school attitudes emerged as a significant predictor, accounting for a unique 26 percent of the variance $(\beta=.53, p<.01)$. In the final step of the model, the interaction between parent participation and child school attitudes was significant, accounting for an additional 7 percent of variance in predicting depressed mood $(\beta=-.28, p=.04)$.

This significant interaction was decomposed by performing a tertile split on child attitudes and regressing depressed mood onto parent participation in subsamples of children with high (score $\geq 53 ; N=11$ ), medium ( $53>$ score $>42 ; N=17$ ) and low (score $\leq 42 ; N=17$ ) attitudes scores. In these simple regressions, parent participation emerged as a significant predictor only for children with the least positive school attitudes, accounting for 41 percent of the variance in child depressed mood $(\beta=-.64 ; p=.03)$. Parent participation did not emerge as a significant predictor of depressed mood for children with medium $\left(R^{2}=.01 ; \beta\right.$ $=-.10 ; p=.69)$ or low (i.e. more positive) school attitudes scores $\left(R^{2}=.02 ; \beta=.15 ; p=\right.$. $56)$.

\section{Dependent variable: school anxiety}

The results for school anxiety are presented in Table 5 .

In the first regression, parent confidence emerged as a significant predictor, accounting for 15 percent of the variance $(\beta=-.39, p<.01)$. Neither child school attitudes nor the interaction of parent confidence and child school attitudes accounted for additional variance in school anxiety. Parent participation accounted for a non-significant 2 percent of the variance in predicting school anxiety. Neither child school attitudes nor the interaction of parent participation and child school attitudes accounted for additional variance in the outcome. The overall model accounted for 6 percent of the variance in school anxiety.

\section{Discussion}

Parent-school partnerships and children's school attitudes were associated directly and interactively with children's internalizing symptoms among this sample of minority, lowincome urban families.

\section{Parents' confidence in school and children's school anxiety}

In what appears to be the first examination of school anxiety among children living with asthma in urban environments, higher levels of parent confidence in the school were associated with fewer symptoms of school anxiety. This correspondence between parents' and children's overall comfort with the school environment is consistent with previous research demonstrating that in families living with pediatric asthma, anxiety and/or stress of parents runs in parallel with children's asthma symptoms (Milam et al., 2008), morbidity (Shalowitz et al., 2001) and internalizing problems (Lim et al., 2008). Symptoms of school anxiety may be indicative of children's overall anxiety as well as a tendency toward coping with school-related stress through avoidance. Notably, parents' use of avoidant coping has been associated concurrently and prospectively with compromises in children's asthmarelated quality of life and greater overall anxiety (Sales et al., 2008). 


\section{Moderating effect of child's school attitudes on depressed mood}

Over and above the effects of parents' confidence and participation in school, children's positive attitudes toward school were related directly to fewer symptoms of depressed mood. Importantly, children's school attitudes also functioned as a moderator in the association between parents' school participation and children's depressed mood. In the subgroup of children with the least positive attitudes toward school, less parental participation accounted for 41 percent of the variance in depressed mood. That is, the children most vulnerable to emotional distress experienced the combination of non-participatory parenting and negative attitudes about school. Oyserman and colleagues (2007) have provided evidence that changes in children's school-focused possible selves (an attitudinal variable) can bring about changes in depressed mood and school-related functioning, which highlights the importance of understanding the family context in which children's attitudes develop over time.

\section{Conclusion}

\section{Empirical implications}

The current findings can inform the construction of future theoretical models. For example, one may suspect intuitively that stronger parent-school partnerships would foster children's positive school attitudes, bringing about fewer internalizing symptoms. Although not explicitly tested, the conditions for such a mediational model of family processes were not met in the current dataset because none of the family-school connection variables were correlated significantly with one another. This is notable, given that the two parent-school partnership variables stemmed from the same instrument. Thus, the current results support the idea that aspects of the parent-school partnership and children's school attitudes function relatively independently and/or in concert with one another rather than through a causal pathway, to influence children's risk.

Future theoretical models should explore family factors which influence the quality of parent-school partnerships. Precedents for such work have been provided by Green and colleagues (2007), who tested a complex theoretical model exploring parents' motivations for school involvement. In the current study, parental education was not correlated with parental confidence or involvement. This fortifies evidence that socioeconomic factors account for less variance in parental involvement when compared to other elements of the social context, such as interpersonal relationships between parents, children and teachers (Green et al., 2007) and the strength of social networks (Waanders et al., 2007). Surprisingly, in this sample, higher parental education was correlated significantly with children's more negative attitudes about school. One could speculate that the families of more highly educated parents feel and convey disillusionment to their children about their experiences in urban schools. However, it will be important for future research to clarify how urban parents' academic experiences and attitudes are linked with their children's approaches to school.

Future research on parent-child anxiety and avoidance among families coping with asthma and urban stressors could yield fruitful implications for interventions to encourage engagement and active coping in the school setting.

\section{Limitations of the study}

The current study addresses an understudied population and a construct (school-related anxiety) which has received no attention in the pediatric asthma literature thus far. However, the findings should be interpreted with caution. The statistical power of this study was limited by a small sample size. The families in this study were drawn from five community health centers which collectively serve a large number of children with asthma. Those that 
participated may not be fully representative of families served in urban community health centers, as they may be characterized by fewer asthma-related and/or life stressors that would pose a barrier to participation. Although the use of multiple reporters is a strength of the study, common method variance may have affected some findings. The direction of relations among variables cannot be determined.

Although the current analyses were conducted with children living with asthma, it is unclear whether these results are representative of children with asthma in particular or children living in urban environments more generally. Asthma severity was not associated significantly with internalizing problems or grades in this sample; previous findings in this regard have been inconsistent (Gupta et al., 2006). The association between asthma severity and children's functioning may be qualified by social context, given the previous finding that adults with more severe asthma exhibited an increased risk for mortality if family or financial problems were present (Barton et al., 2005; Mcquaid et al., 2001). If asthma exerts a differential effect on children's functioning in the higher ranges of severity, this tendency would not have been detected within the current sample for which the mean severity level was in the mild/intermittent to mild/persistent range. Further research is needed to examine asthma control as a covariate of children's psychological and academic functioning.

\section{Clinical implications}

The current findings are consistent with the previous literature documenting an association between greater parental involvement in school and more positive child-school functioning (Henderson and mapp, 2002), and calling for the implementation of organized programs to foster stronger family-school connections, particularly among low-income families (Van Velsor and Orozco, 2007). There is evidence that initiating an organized program to foster family-school partnerships can act as a mechanism to improve children's school attendance across a period of one year (Sheldon, 2007), an outcome that is particularly relevant for families coping with asthma. Specific strategies for improving family-school connections can address multiple levels of the ecosystem (see Sheldon, 2007; Van Velsor and Orozco, 2007). Schools can encourage and support teacher-initiated direct parent contact regarding children's positive performance. On-site services and activities which address families' needs, presented at times that fit families' diverse schedules, may help to draw parents in to become familiar and comfortable in the school. Within school systems, teachers and administrators can learn about the communities that they serve, including other agencies that serve families and forge relationships with community leaders. When school personnel embrace and value the community culture and view families through a strength-based lens, schools are enabled to create meaningful opportunities for parents to engage with and invest in the school.

\section{Acknowledgments}

Funding for this study was provided by a grant awarded to the first author by the National Institutes of Health (MH63165). Appreciation is expressed to Carolyn Greene, Ana Diaz and Yudy muneton for their assistance in the conceptualization and implementation of the study.

\section{References}

American Lung Association, Epidemiology and Statistics Unit, Research and Program Services. Trends in Asthma Morbidity and Mortality. 2007. URL (consulted 15 September 2008): http:// www.lungusa.org/atf/cf/\%7B7a8d42c2-fcca-4604s-8ade7f5d5e762256\%7D/ ASTHMA_TREND_NOV2007.PDF

Adams, KS. PhD thesis. University of Minnesota; 1997. Trust within the Home-School Partnership: an Empirical Investigation of Parent and Teacher Perspectives. 
Adler NE, Epel ES, Castellazzo G, Ickovics JR. Relationship of Subjective and Objective Social Status with Psychological and Physiological Functioning: Preliminary Data in Healthy White Women. Health Psychology. 2000; 19(6):586-92. [PubMed: 11129362]

Alati R, O’Callaghan M, Najman J, Williams G, Bor W, Lawlor D. Asthma and Internalizing Behavior Problems in Adolescence: a Longitudinal Study. Psychosomatic Medicine. 2005; 67(3):462-70. [PubMed: 15911911]

Barton CA, McKenzie DP, Walters EH. Interactions between Psychosocial Problems and Management of Asthma: Who Is at Risk of Dying? Journal of Asthma. 2005; 42(4):249-56. [PubMed: 16032933]

Bell-Dolan D, Wessler A. Attributed Style of Anxious Children: Extentions from Cognitive Theory and Research on Adult Anxiety. Journal of Anxiety Disorders. 1994; 8(1):79-96.

Bender BG. Are Asthmatic Children Educationally Handicapped? School Psychology Quarterly. 1995; 10(4):274-91.

Bender BG, Lerner JA, Poland JE. Association between Corticosteroids and Psychologic Change in Hospitalized Asthmatic Children. Annals of Allergy. 2001; 66(5):414-9. [PubMed: 2035905]

Birmaher B, Bridge J, Williamson D. Psychosocial Functioning in Youths at High Risk to Develop Major Depressive Disorder. Journal of the American Academy of Child and Adolescent Psychiatry. 2004; 43(7):839-46. [PubMed: 15213585]

Blatchford P. Pupils' View on School Work and School From 7 to 16 Years. Research Papers in Education. 2007; 11(3):263-88.

Bronfenbrenner U. Contexts of Child Rearing: Problems and Prospects. American Psychologist. 1979; 34(10):844-50.

Bronfenbrenner, U. Developmental Ecology through Space and Time: a Future Perspective. In: Moen, P.; Elder, GH.; Lüscher, K., editors. Examining Lives in Context: Perspectives on the Ecology of Human Development. American Psychological Association; Washington, DC: 1995. p. 619-47.

Bronfenbrenner, U.; Morris, PA. The Ecology of Developmental Processes. In: Damon, W.; Lerner, RM., editors. Handbook of Child Psychology: Volume 1: Theorectical Models of Human Development. 5th edn. John Wiley \& Sons; Hoboken, NJ: 1998. p. 993-1028.

Brown E, Khan D, Maleaedi S. Psychiatric Diagnosis in Inner-city Outpatients with Moderate to Severe Asthma. International Journal of Psychiatry in Medicine. 2000; 30(4):319-27. [PubMed: 11308036]

Castro M, Schechtman K, Halstead J, Bloomberg G. Risk Factors for Asthma Morbidity and Mortality in a Large Metropoltan City. Journal of Asthma. 2001; 38(8):625-35. [PubMed: 11758891]

Cherian VI, Cherian L. Attitudes of Parents and Guardians Towards Education, School and Teachers and Children's Academic Achievement. Psychological Reports. 1996; 79(3):1387-90.

Chorpita, B.; Southam-Gerow, M. Fears and Anxieties. In: Marsh, E.; Barkley, R., editors. Treatment of Childhood Disorders. 3rd edn. Guilford Press; New York: 2006. p. 271-335.

Christenson, SL.; Rounds, T.; Franklin, MJ. Home-School Collaboration: Effects, Issues and Opportunities. In: Christenson, SL.; Conoley, JC., editors. Home-School Collaboration: Enhancing Children's Academic and Social Competence. NASP; Colesville, MD: 1992. p. 19-51.

Compton-Lily C. Staying on Children: Challenging Stereotypes about Urban Parents. Language Arts. 2000; 77(5):420-7.

Diehl DS, Lemerise EA, Caverly SL, Roberts J, Ramsay S. Peer Relations and School Adjustment in Ungraded Primary Children. Journal of Educational Psychology. 1998; 90(3):506-15.

Diette G, Markson L, Skinner E, Nguyen T, Algatt-Bergstrom P, Wu A. Nocturnal Asthma in Children Affects School Attendance, School Performance and Parents' Work Attendance. Archives of Pediatrics and Adolescent Medicine. 2000; 154(9):923-8. [PubMed: 10980797]

Epstein, J. School and Family Connections: Theory, Research and Implications for Integrating Sociologies of Education and Family. In: Unger, D.; Sussman, M., editors. Families in Community Settings: Interdisciplinary Perspectives. Haworth Press; New York: 1990. p. 99-126.

Fowler MG, Davenport MG, Garg R. School Functioning of US Children with Asthma. Pediatrics. 1992; 90(6):939-44. [PubMed: 1437438]

Goodwin R, Messineo K, Bregante A, Hoven C, Kairam R. Prevalence of Probable Mental Disorders among Pediatric Asthma Patients in an Inner-city Clinic. Journal of Asthma. 2005; 42(8):643-7. [PubMed: 16266954] 
Goodwin R, Pine D, Hoven C. Asthma and Panic Attacks among Youth in the Community. Journal of Asthma. 2003; 40(2):139-45. [PubMed: 12765315]

Green C, Walker J, Hoover-Dempsey K, Sandler H. Parents' Motivations for Involvement in Children's Education: an Empirical Test of a Theoretical Model of Parental Involvement. Journal of Educational Psychology. 2007; 99(3):532-44.

Gupta S, Crawford S, Mitchell I. Screening Children with Asthma for Psychosocial Adjustment Problems: a Tool for Health Care Professionals. Journal of Asthma. 2006; 43(7):543-8. [PubMed: 16939996]

Gutstadt LB, Gillette JW, Mrazek DA, Fukuhara JT, LaBrecque JF, Strunk RC. Determinants of School Performance in Children with Chronic Asthma. American Journal of Diseases of Children. 1989; 143(4):471-5. [PubMed: 2929529]

Halterman JS, Montes G, Aligne CA, Kaczorowski JM, Hightower AD, Szilagyi PG. School Readiness among Children with Asthma. Pediatrics. 2001; 1(4):201-5.

Henderson, A.; Mapp, K. A New Wave of Evidence: the Impact of School, Family and Community Connections on Student Achievement. Southwest Educational Developmetal Laboratory; Austin, TX: 2002.

Josie K, Greenley R, Drotar D. Cumulative Risk and Asthma Outcomes in Inner-city AfricanAmerican Youth. Journal of Asthma. 2007; 44(7):535-41. [PubMed: 17885856]

Katon WJ, Richardson L, Russo J, Lozano P, McCauley E. Quality of Mental Health Care for Youth with Asthma and Comorbid Anxiety and Depression. Medical Care. 2006; 44(12):1064-72. [PubMed: 17122709]

Kearney CA, Bensaheb A. School Absenteeism and School Refusal Behavior: a Review and Suggestions for School-based Health Professionals. Journal of School Health. 2006; 76(1):3-7. [PubMed: 16457678]

Kearney CA, Eisen AR, Silverman WK. The Legend and Myth of School Phobia. School Psychology Quarterly. 1995; 10(1):65-85.

Kendall P, Kortlander E, Chansky T, Brady E. Comorbidity of Anxiety and Depression in Youth: Treatment Implications. Journal of Consulting and Clinical Psychology. 1992; 60(6):869-80. [PubMed: 1360989]

Koinis Mitchell D, Adams S, Murdock K. Associations among Risk Factors, Individual Resources and Indices of School-related Asthma Morbidity in Urban, School-aged Children: a Pilot Study. Journal of School Health. 2005; 75(10):375-83. [PubMed: 16313508]

Langley A, Bergman R, McCracken J, Piancentini J. Impairment in Childhood Anxiety Disorders: Preliminary Examination of the Child Anxiety Impact Scale-Parent Version. Journal of Child and Adolescent Psychopharmacology. 2004; 14(1):105-14. [PubMed: 15142397]

Lim J, Wood L, Miller B. Maternal Depression and Parenting in Relation to Child Internalizing Symptoms and Asthma Disease Activity. Journal of Family Psychology. 2008; 22(2):264-73. [PubMed: 18410213]

McLoyd VC. Socioeconomic Disadvantage and Child Development. American Psychologist. 1998; 53(2):185-204. [PubMed: 9491747]

McQuaid EL, Kopel SJ, Nassau JH. Behavioral Adjustment in Children with Asthma: a Meta-analysis. Journal of Developmental and Behavioral Pediatrics. 2001; 22(6):430-9. [PubMed: 11773808]

Meuret A, Ehrenreich J, Pincus D. Prevalence and Correlates of Asthma in Children with Internalizing Psychopathology. Depression and Anxiety. 2006; 23(8):502-8. [PubMed: 16841339]

Milam J, McConnell R, Yao L, Berhane K, Jerrett M, Richardson J. Parental Stress and Childhood Wheeze in a Prospective Cohort Study. Journal of Asthma. 2008; 45(4):319-23. [PubMed: 18446597]

Moonie S, Sterling D, Figgs L, Castro M. Asthma Status and Severity Affects Missed School Days. Journal of School Health. 2006; 76(1):18-24. [PubMed: 16457681]

Nakao, K.; Treas, J. Computing 1989 Occupational Prestige Scores. National Opinion Research Center; Chicago, IL: 1990.

National Institutes of Health, National Heart, Lung and Blood Institute, National Asthma Education and Prevention Program. Clinical Practice Guidelines. National Institutes of Health; Bethesda, 
MD: 2002. Expert Panel Report: Guidelines for the Diagnosis and Management of Asthma Update on Selected Topics 2002. NIH Publication No. 02-5075

Newacheck P, Halfon N. Prevalence, Impact and Trends in Childhood Disability Due to Asthma. Archives of Pediatrics and Adolescent Medicine. 2000; 154(3):287-93. [PubMed: 10710030]

Oyserman D, Brickman D, Rhodes M. School Success, Possible Selves and Parent School Involvement. Family Relations. 2007; 56(5):479-89.

Padur JS, Rapoff MA, Houston BK, Barnard M, Danovsky M, Olson NY. Psychosocial Adjustment and the Role of Functional Status for Children with Asthma. Journal of Asthma. 1995; 32(5):34553. [PubMed: 7559275]

Rana U, Jurgens S, Mangione S, Elia J, Tollerud D. Asthma Prevalence among High Absentees of Two Philadelphia Middle Schools. Chest. 2000; 118(4):795. Abstract. [PubMed: 10988205]

Reynolds, CR.; Kamphaus, RW. BASC: Behavioral Assessment System for Children Manual. American Guidance Services; Circle Pines, NJ: 1998.

Ross CJM, Davis TMA, Hogg DY. Screening and Assessing Adolescent Asthmatics for Anxiety Disorders. Clinical Nursing Research. 2007; 16(1):5-24. [PubMed: 17204805]

Russell, TT.; Russell, DK. The Relationship between Childhood Depression, Perceptions of Family Functioning and Perceptions of Classroom Social Climate: Implications for School Counselors. US Department of Education; Washington, DC: 1996.

Sales J, Fivush R, Teague G. The Role of Parental Coping in Children with Asthma's Psychological Well-being and Asthma-related Quality of Life. Journal of Pediatric Psychology. 2008; 33(2):20819. [PubMed: 17717005]

Shalowitz M, Berry C, Quinn K, Wolf R. The Relationship of Life Stressors and Maternal Depression to Pediatric Asthma Morbidity in a Subspeciality Practice. Ambulatory Pediatrics. 2001; 1(4):18593. [PubMed: 11888399]

Sheldon S. Improving Student Attendance with School, Family and Community Partnerships. Journal of Educational Research. 2007; 100(5):267-75.

Shumow L, Vandell D, Posner J. Risk and Resilience in the Urban Neighborhood: Predictors of Academic Performance among Low-income Elementary School Children. Merrill-Palmer Quarterly. 1999; 45(2):309-31.

Silverman, WK.; Ginsburg, G. Anxiety Disorders. In: Ollendick, T.; Herson, M., editors. Handbook of Child Psychopathology. 3rd edn. Plenum Press; New York: 1998. p. 239-68.

Taras H, Potts-Detema W. Childhood Asthma and Student Performance at School. Journal of School Health. 2005; 75(8):296-312. [PubMed: 16179080]

United States Census Bureau. Modified Race Data Summary File: 2000 Census of Population and Housing. 2002. URL (consulted 29 April 2009): http://www.census.gov/popest/archives/files/ MRSF-01-US1.html\#c2rc

Van Velsor P, Orozco G. Involving Low-income Parents in the Schools: Community-centric Strategies for School Counselors. Professional School Counseling. 2007; 11(1):17-24.

Vila G, Nollet-Clemencon C, de Blic J, Mouren-Simeoni M, Scheinmann P. Prevalence of DSM IV Anxiety and Affective Disorders in a Pediatric Population of Asthmatic Children and Adolescents. Journal of Affective Disorders. 2000; 58(3):223-33. [PubMed: 10802131]

Waanders C, Mendez J, Downer J. Parent Characteristics, Economic Stress and Neighborhood Context as Predictors of Parent Involvement in Preschool Children's Education. Journal of School Psychology. 2007; 45(6):619-36. 


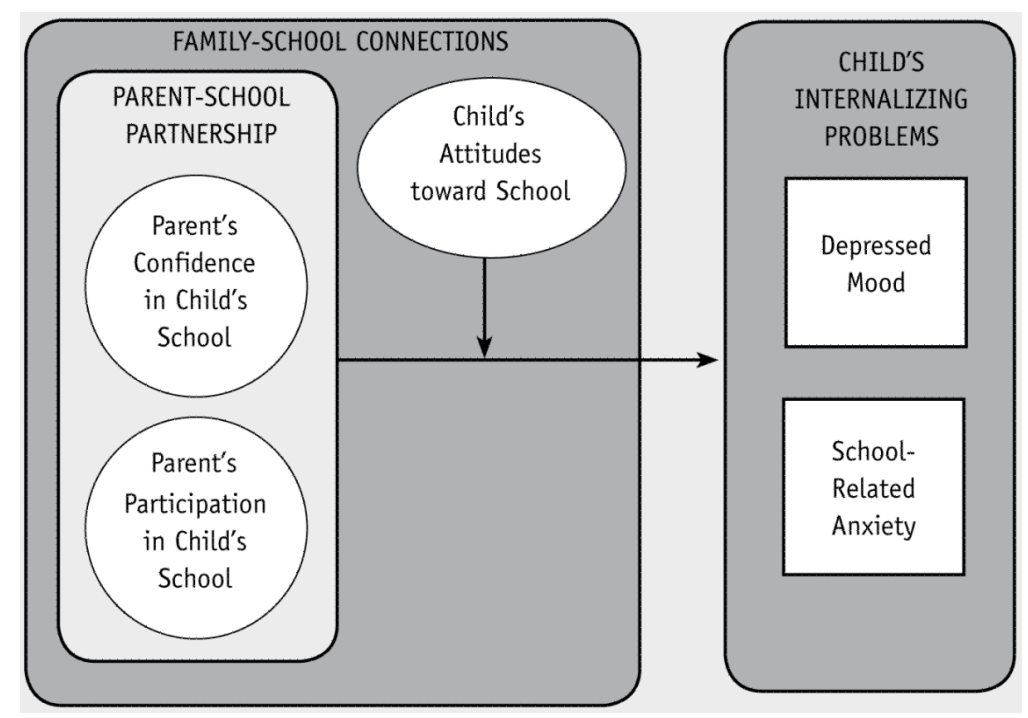

Figure 1.

: Hypothetical model proposing school attitudes as a moderator between family-school connections and children's internalizing problems 


\section{Table 1}

Descriptive data for study variables $(n=45)$

$\begin{array}{lccc}\text { Variable } & \text { Mean (SD) } & \begin{array}{c}\text { Possible } \\ \text { Range }\end{array} & \begin{array}{c}\text { Range in } \\ \text { Sample }\end{array} \\ \text { Primary Study Variables Not Included in Model } & & 1-82(.94) & 1-4 \\ \text { Asthma severity } & 3.87(0.86) & 1-5 & 2-5 \\ \text { Grades in school } & & & \\ \text { Predictor Variables } & 38.62(4.94) & 11-44 & 28-44 \\ \quad \text { Parent confidence } & 9.25(3.31) & 3-15 & 3-15 \\ \quad \text { Parent participation } & 47.47(7.74) & 1-100 & 38-64 \\ \quad \text { Child school attitudes } & & & \\ \text { Outcome Variables } & 54.71(9.66) & 1-100 & 41-80 \\ \quad \text { Depressed mood } & 5.84(1.19) & 5-10 & 5-9 \\ \quad \text { School anxiety } & & \end{array}$


Table 2

Demographic Characteristics of Participants $(n=45)$

\begin{tabular}{|c|c|c|c|c|}
\hline Variable & $\%$ of sample & Mean & SD & Range \\
\hline \multicolumn{5}{|l|}{ Child Characteristics } \\
\hline Child's age (years) & & 9.3 & 1.2 & $7-12$ \\
\hline \multicolumn{5}{|l|}{ Child's gender } \\
\hline Female & $51 \%$ & & & \\
\hline Male & $49 \%$ & & & \\
\hline Child's race/ & $38 \%$ African-American; & & & \\
\hline \multirow[t]{2}{*}{ ethnicity } & 38\% Hispanic; 9\% Multiracial; & & & \\
\hline & $9 \%$ White; $6 \%$ Unknown & & & \\
\hline \multicolumn{5}{|l|}{ Caregiver's Characteristics } \\
\hline \multicolumn{2}{|c|}{ Primary Caregiver's age (years) } & 37.9 & 10.1 & $20-65$ \\
\hline \multicolumn{5}{|l|}{ Primary Caregiver's gender } \\
\hline Female & $97.8 \%$ & & & \\
\hline Male & $2.2 \%$ & & & \\
\hline Primary Caregiver's & 40\% African-American; & & & \\
\hline \multirow[t]{2}{*}{ race/ethnicity } & 38\% Hispanic; 4\% Multiracial; & & & \\
\hline & 9\% White; 9\% Unknown & & & \\
\hline \multirow[t]{6}{*}{ Education level } & $22.2 \%$ Did not finish high school & & & \\
\hline & $35.5 \%$ High school graduate/GED & & & \\
\hline & $15.6 \%$ Vocational training & & & \\
\hline & $17.8 \%$ Associates degree equivalent & & & \\
\hline & $8.9 \%$ College graduate & & & \\
\hline & $0 \%$ Postgraduate Degree & & & \\
\hline \multirow[t]{2}{*}{ Occupational Status } & $55.6 \%$ Not employed; & & & \\
\hline & 15.6\% Part-time; $28.9 \%$ Full-time & & & \\
\hline \multicolumn{2}{|l|}{ Occupational Prestige } & 41.03 & & \\
\hline \multicolumn{2}{|l|}{ Subjective SES } & 5.07 & 2.36 & $1-10$ \\
\hline \multicolumn{5}{|l|}{ Family Characteristics } \\
\hline \multicolumn{2}{|l|}{ Family's monthly income } & $\$ 1,485$ & $\$ 930.60 \$$ & $389-\$ 4,500$ \\
\hline \multirow[t]{5}{*}{ Free Lunch } & $79.5 \%$ Received a free lunch & & & \\
\hline & $6.8 \%$ Received a reduced & & & \\
\hline & price lunch & & & \\
\hline & $13.5 \%$ Did not receive reduced & & & \\
\hline & or free lunch & & & \\
\hline
\end{tabular}




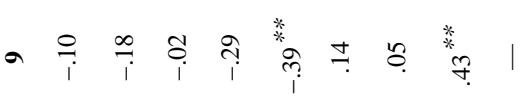

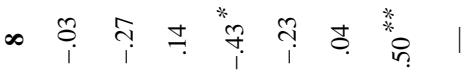

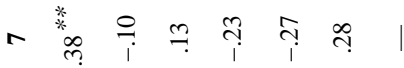

- o. ฮ.

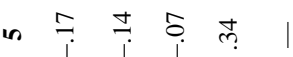

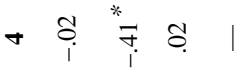

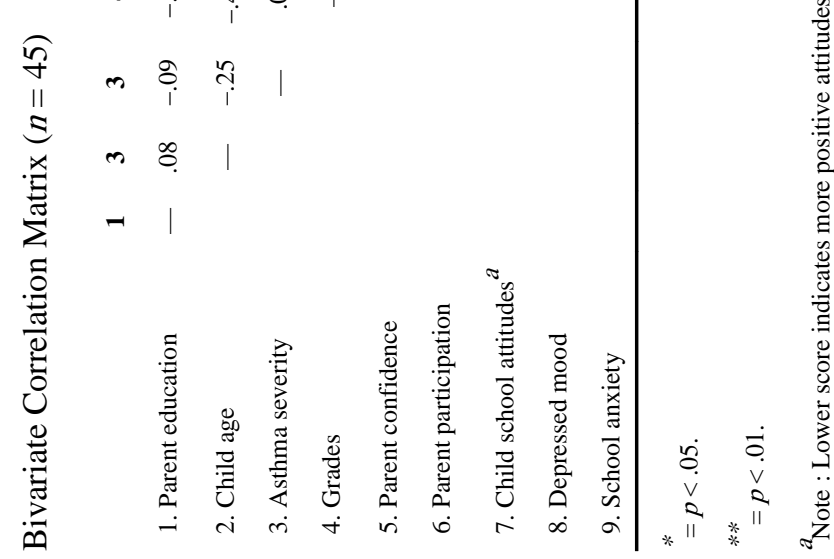

J Child Health Care. Author manuscript; available in PMC 2012 October 25. 
